\title{
Unraveling the Functions of the Macroalgal Microbiome
}

\author{
Ravindra Pal Singh ${ }^{1,2 *}$ and C. R. K. Reddy ${ }^{2,3 *}$ \\ ${ }^{1}$ Laboratory of Microbial Technology, Department of Bioscience and Biotechnology, Graduate School, Faculty of Agriculture, \\ Kyushu University, Fukuoka, Japan, ${ }^{2}$ Seaweed Biology and Cultivation, Division of Marine Biotechnology and Ecology, \\ Council of Scientific and Industrial Research-Central Salt and Marine Chemicals Research Institute, Bhavnagar, India, \\ ${ }^{3}$ Academy of Scientific and Innovative Research, New Delhi, India
}

OPEN ACCESS

Edited by:

Olga Lage,

University of Porto, Portugal

Reviewed by:

Mia Bengtsson,

University of Vienna, Austria

Christophe Destombe,

Université Pierre et Marie Curie,

France

*Correspondence:

C. R. K. Reddy

crk@csmcri.org;

Ravindra Pal Singh

ravindrapal.1441@gmail.com

Specialty section:

This article was submitted to

Aquatic Microbiology,

a section of the journal

Frontiers in Microbiology

Received: 29 September 2015 Accepted: 10 December 2015

Published: 05 January 2016

Citation:

Singh RP and Reddy CRK (2016)

Unraveling the Functions

of the Macroalgal Microbiome.

Front. Microbiol. 6:1488.

doi: 10.3389/fmicb.2015.01488
Macroalgae are a diverse group of photosynthetic eukaryotic lower organisms and offer indispensable ecosystem services toward sustainable productivity of rocky coastal areas. The earlier studies have mainly focused on elucidation of the roles of the epiphytic bacterial communities in the ecophysiology of the host macroalga. However, mutualistic interactions have become topic of current interest. It is evident from recent studies that a fraction of epiphytic bacterial communities can be categorized as "core microbial species", suggesting an obligate association. Epiphytic bacterial communities have also been reported to protect macroalgal surfaces from biofouling microorganisms through production of biologically active metabolites. Because of their intrinsic roles in the host life cycle, the host in turn may provide necessary organic nutrients in order to woo pelagic microbial communities to settle on the host surfaces. However, the precise composition of microbiomes and their functional partnership with hosts are hardly understood. In contrast, the microbial studies associated with human skin and gut and plants have significantly advanced our knowledge on microbiome and their functional interactions with the host. This has led to manipulation of the microbial flora of the human gut and of agricultural plants for improving health and performance. Therefore, it is highly imperative to investigate the functional microbiome that is closely involved in the life cycles of the host macroalgae using high-throughput techniques (metagenomics and metatranscriptomics). The findings from such investigations would help in promoting health and productivity in macroalgal species through regulation of functionally active microbiome.

Keywords: macroalgae, bacteria, functional species, cultivation, health

\section{INTRODUCTION}

Most animals and plants rely on the subtle interactions of specific microorganisms for their successful sustenance. The emergence of high-throughput technologies has recently provided newer insights in understanding the complex interactions of microorganisms with diverse hosts such as the human gut, plant rhizosphere, and sponge microbiomes at an unprecedented depth (Turnbaugh et al., 2007; Berg and Smalla, 2009; Yang and Li, 2012). These microbiomes are highly diverse and are functionally connected with their eukaryotic hosts. Thus, these associations are now termed holobionts (Zilber-Rosenberg and Rosenberg, 2008). Particularly, microorganisms that colonize different parts of the human, coral, sponge, and plant bodies contain specific 
functional genes which are now regarded as secondary genomes (Siboni et al., 2008; Grice et al., 2009; Lebeis et al., 2012; Bulgarelli et al., 2013). The application of metagenomics has provided significant new information with respect to interaction of phyllospheric, rhizospheric, and endospheric microbiomes of higher plants. The prevailing environmental conditions have also been considered to be potential drivers for shaping and determining the host microbiome (Turner et al., 2013). Secondary metabolites (flavonoids) have also been shown as key determinants for formation of plant-specific rhizospheric microbiomes (Weston and Mathesius, 2013). Furthermore, investigation of the human gut and the plant rhizospheric microbiomes has provided new means for modulation of specific microbial communities in order to reduce disease incidence particularly in the former host (Andrews, 1992; Bloemberg and Lugtenberg, 2001), and chemical inputs (Adesemoye et al., 2009) and emission of greenhouse gases (Singh et al., 2010) in the latter to accelerate agricultural productivity (Bakker et al., 2012). Similarly, macroalgal growth and development are shown to depend on associated microorganisms, particularly bacterial communities (Singh and Reddy, 2014; Wichard et al., 2015). Despite the publishing of several interesting findings regarding the interaction of macroalgae and their bacterial communities in last decade, the functional diversity and connectivity of these communities with the host is yet to be tapped.

In regard to the functional connection between macroalgae and their associated bacteria, it has been reported that bacterial cells chemically communicate with the host and symbiotically assist in the processes of growth, morphogenesis, and reproduction (Chisholm et al., 1996; Joint et al., 2002; Matsuo et al., 2005) by modulating the abiotic and biotic interactions of the association (Wahl et al., 2012). Functional understanding of the chemical signaling in the macroalgal-bacterial interaction is also limited as compared to higher plants (Hartmann et al., 2014), despite the presence of ecophysiological evidences since a long time (Provasoli and Pintner, 1980). Therefore, in this article, we emphasize the need for re-investigating the existing knowledge of bacterial assistance in the life cycle of macroalgae using high-throughput technologies to understand the functions of the macroalgal microbiome and host responses.

\section{MACROALGAE AS IMPORTANT MARINE HABITAT FORMERS AND A GROWING ECONOMIC RESOURCE}

The macroalgal canopy at intertidal regions is important for safeguarding intertidal ecosystems. For example, removal of macroalgal species can modify the local habitat and alter the impact of spatial complexity on the surrounding benthic species (Tait and Schiel, 2011). It has also been observed that declining intertidal macroalgal species leads to a loss of associated species that rely on the established algal canopy (Komatsu et al., 2014). Macroalgae also have immense commercial value. They are rich in minerals and essential trace elements required for human consumption as well as important sources of raw materials for fertilizers, hydrocolloids, and biofuel industries (Kumari et al.,
2010; Baghel et al., 2015). Growing energy demands and rapidly depleting fossil fuel reserves have collectively stimulated the search for sustainable alternative bioenergy sources and supplies (Hahn-Hägerdal et al., 2006). In this context, macroalgae have recently been recognized as a potential source of renewable biofuel and bioenergy (Baghel et al., 2015). Due to industrial demands, they are commercially cultivated in a number of countries (Loureiro et al., 2015). Several industries provide a wide variety of products derived from macroalgae that have an estimated total annual value of US\$ 5.5-6 billion. Additionally, diverse food products processed from macroalgal raw materials have a contributed value of over US\$ 5 billion (FAO, 2014). Thus, increasing the gross production of industrially important macroalgal species is required for fulfilling human demands. For this purpose, identifying the functionally active microbial species associated with them could accelerate their production through appropriate modulation.

\section{MACROALGAL MICROBIOMES ASSIST IN HOST LIFE CYCLE}

Epiphytic and endophytic bacterial communities have been extensively studied in the context of their phylogenetic composition and variability on or in macroalgae (Staufenberger et al., 2008; Lachnit et al., 2011; Hollants et al., 2013). These studies have used morphological characterization, in situ hybridization, electrophoresis, DNA finger printing, pyrosequencing, and metagenomic approaches (Tujula et al., 2010; Burke et al., 2011b; Hollants et al., 2011, 2013; Lachnit et al., 2011; Bengtsson et al., 2012; Bondoso et al., 2014). These findings suggest that bacterial communities belonging to the phyla Proteobacteria and Firmicutes are generally the most abundant epiphytic bacteria associated with macroalgal hosts.

Studies from previous decades have also revealed the role of epiphytic bacteria in the ecophysiology of macroalgal hosts. The importance of bacteria in macroalgal research began with the study by Provasoli and Pintner (1953), who reported that plant growth regulators (indol-3-acetic acid) regulate growth and morphogenesis in Ulva species. Provasoli (1958) reported that an axenic culture of Ulva did not develop into normal foliose morphology and showed polymorphic behavior. Later, it was observed that Ulva species retained normal foliose structures when their cultures were inoculated with specific bacterial communities (Tatewaki et al., 1983). In fact, this observation was attributed to thallusin, a bacterial compound obtained from the specific bacterial strain YM2-23 which was found to restore normal thallus morphology (Matsuo et al., 2005). Additionally, some bacterial species produce regulatory compounds resembling cytokinin (from Roseobacter, Sulfitobacter, and Halomonas) and auxin (from Cytophaga) that assist in the differentiation of $U$. mutabilis (Spoerner et al., 2012). Interestingly, unidentified metabolites from Grampositive bacteria have also been found to induce morphogenesis in Ulva species (Marshall et al., 2006; Singh et al., 2011). These findings suggest the possibility that these unidentified compounds may have broad-spectrum activities with possible 
host benefits. Thus, such potential compounds should be identified by further studies.

Discovery of the quorum sensing (QS) system as a mechanism of cooperative behavior in bacteria (Fuqua et al., 1994) was yet another revolutionary subject of interest. QS has been defined as the cell-cell communication system that exists between same and different bacterial populations and depends on the threshold concentration of cells (Rutherford and Bassler, 2012). A group of QS signaling compounds, $N$-acyl homoserine lactones (AHLs) secreted by Gram-negative bacteria has gained significant attention in higher plants due to several phenomena of plant life cycles being controlled by AHLs via inter-kingdom communication system (Venturi and Fuqua, 2013; Hartmann et al., 2014). Interestingly, macroalgae are also involved in interkingdom communication through AHLs, and earlier studies have indeed demonstrated that AHLs promote the settlement of zoospores in green macroalgae (Joint et al., 2002) and liberation of carpospores in some red macroalgae (Weinberger et al., 2007; Singh et al., 2015). Thus, it is essential to determine the molecular mechanisms involved in these reported chemical cues in macroalgal hosts through further studies.

Additionally, many fundamental questions regarding chemical signaling systems and the interactive functions of macroalgal-bacterial interaction remain to be resolved for a better understanding of the macroalgal microbiome. For examples, two aspects of the bacterial role in macroalgal life cycles have been well studied, (a) their role in host reproduction and growth and (b) the induction of morphogenesis in green macroalgae. Despite these, we do not know how these phenomena are regulated by signaling cascades or the kinds of secondary molecules involved and how these phenomena are regulated at the DNA, RNA, and protein levels of this association. Thus, we would like to suggest that future studies should emphasize on meta-omics technologies to understand the macroalgal microbiome in depth.

\section{NEXT-GENERATION TOOLS FOR UNVEILING FUNCTIONAL BACTERIAL GENOMICS OF MACROALGAL MICROBIOME}

Next-generation sequencing (NGS) technologies (metagenomics and metatranscriptomics) have had a dramatic impact on the field of microbial genomic research through stipulation of low cost and high-throughput sequencing systems such as Hi-Seq and Mi-Seq (Caporaso et al., 2012). These NGS technologies follow high-throughput and powerful analytical methods called "metabolomics" to monitor the actual physiological state of microbial communities. Another technique, called "metaproteomics," determines the actual post-transcriptionally regulated and translated microbial proteins under a given condition in addition to unveiling the active molecular interactions of the microbiome (Figure 1). The technical details of these meta-omics technologies have been comprehensively reviewed elsewhere (Mardis, 2008; Metzker, 2010; Schadt et al., 2011; Tang, 2011; Kolmeder and de Vos, 2014) and are not discussed here. Instead, this section briefly summarizes these technologies in context of their potential applications in functional bacterial genomics of the macroalgal microbiome with examples from human and plant microbiomes.

Metagenomics refers to the culture-independent method that is used to explore genetic diversity, population structure, and interactions of microbial communities in their ecosystems. This approach has identified at least 5000 novel, out of 19,000 functional gene clusters annotated from human microbiome projects such as the MetaHIT (http://www.metahit.eu). Many of the genes comprised in the core metagenome are essential for the healthy and proper functioning of the intestinal ecosystem (Qin et al., 2010). Knowledge of this association allows the development of a new range of diagnostic techniques and therapeutics to modulate, enhance, and maintain intestinal homeostasis and thus promote intestinal activities (Turnbaugh et al., 2006; Tana et al., 2010; Kostic et al., 2012) and general health (Wang et al., 2011). Similarly, metagenomics has provided significant knowledge of plant microbiomes (Turner et al., 2013) and has been applied to increase plant health and growth as aforementioned and reported by Mendes et al. (2011). Macroalgae associated bacterial communities are paramount for the host life cycle; however, functional information from culture independent bacterial communities is poorly understood, especially from red and brown macroalgae (Singh and Reddy, 2014). A previous metagenomic study by Burke et al. (2011a) identified several important clusters of orthologous groups (COGs) in bacterial communities associated with $U$. australis that were related to the algal host environment, such as degradation of host secreted metabolites, overcoming host oxidative burst defense mechanisms, storage of heavy metals, and desiccation. Additionally, several cluster homologues to COG0642 (histidine kinase) that are involved in nitrate reduction, motility, QS system, osmoregulation, cell differentiation, plant virulence, and related to defense (involved in host defense by inhibiting growth of other bacteria present in pelagic form) were found. Abundance of these genes in associated bacterial communities indicated that these mediated interaction with the host and other prokaryotic and eukaryotic communities (Burke et al., 2011a). However, it is not known whether these functional bacterial clusters are actively involved in macroalgal-bacterial interaction or whether these clusters can be used for modulating the macroalgal microbiome for defense and growth. Thus, it is important to perform other meta-omics studies (as mentioned below) parallel to metagenomics in order to specify the physiological status of specific functional bacterial communities.

Metatranscriptomics is recognized as a far more accurate method of measuring the levels of transcripts induced by any compound as compared to other methods (Wang et al., 2009). Metatranscriptomic analysis can show a substantial fraction of differentially regulated microbial transcripts from a microbiome sample (Bikel et al., 2015). Metatranscriptomics can be applied to associated bacterial communities to understand the precise level of functional connection of the host microbiome. Metagenomics in combination with metatranscriptomics has unveiled several interesting facts. For example, specific induction of microbial genes in the gut microbiome has been observed 


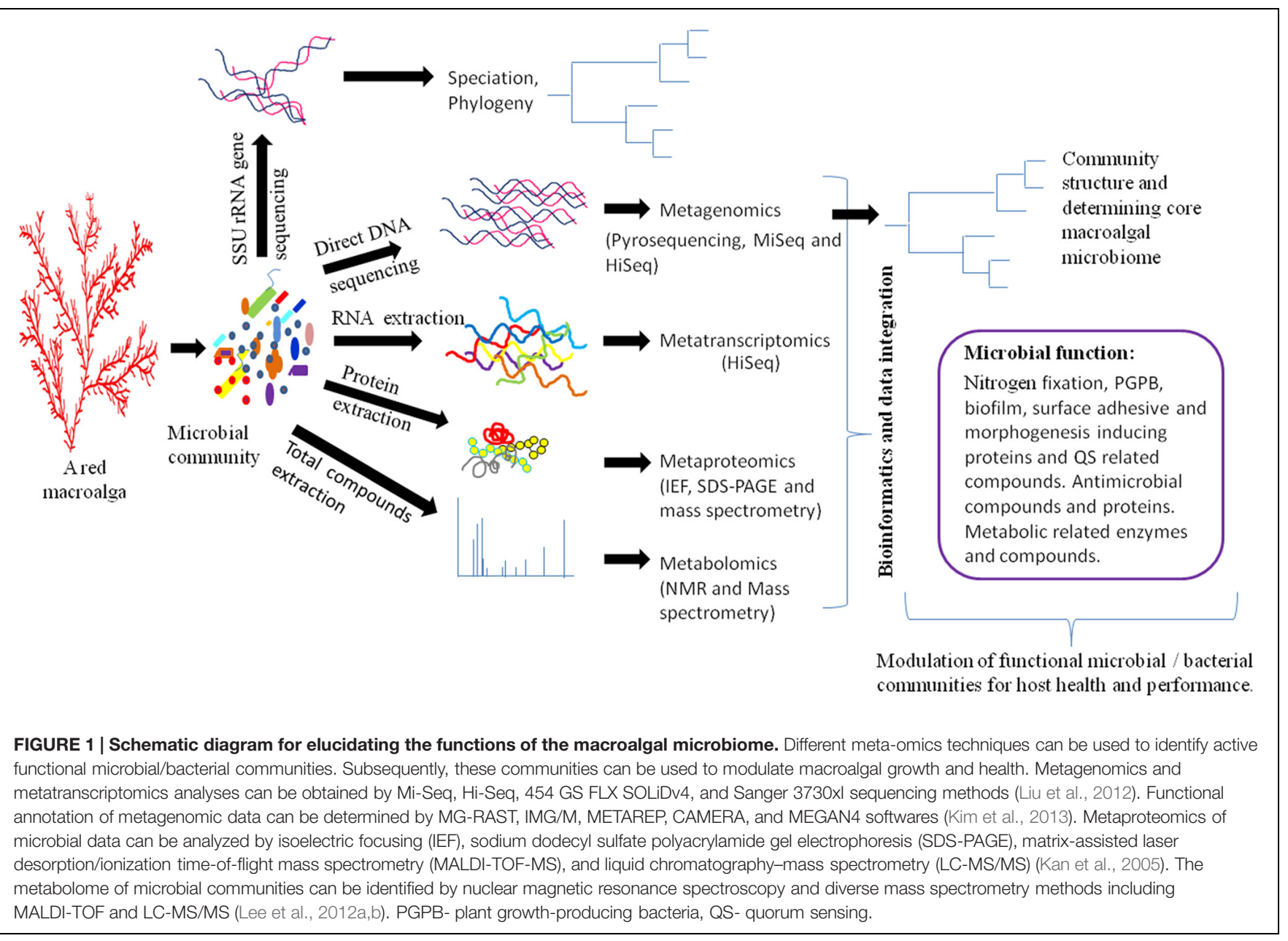

in response to host targeted exposure of xenobiotics (Ursell and Knight, 2013). Recently, transcriptomics analysis has been applied to the red macroalga (Laurencia dendroidea) and their associated microbiome (de Oliveira et al., 2012). Transcripts of associated bacterial communities were highly related to glycolysis, lipid, and polysaccharide breakdown indicating that associated bacteria rely on carbohydrate sources secreted by the host for energy. Amino acid metabolism related transcripts suggested that compounds relevant to nitrogen fixation are exchanged between the host and bacteria. The study also found transcripts related to cell motility and chemotaxis for recognizing the macroalgal surface and establishment of biofilm as well as infection related transcripts particularly of vanadium-dependent bromoperoxidases in associated bacterial communities. RNA transcripts related to oxidative stress mechanisms indicated that the macroalgal associated microbiome utilized aerobic metabolism and also minimized the oxidative burst mechanism in macroalgae (Weinberger, 2007). Elevated transcripts of the QS system indicated that the presence of significant intra- and inter-kingdom communication, which is scarcely understood in comparison with higher plant systems (Hartmann et al., 2014). Many transcripts found in the bacterial communities of $L$. dendroidea are congruent with COGs of metagenomic clusters found in bacterial communities of $U$. australis, indicating that integrated chemical interaction occurs in this association. Thus, performing a metatranscriptomics study in the context of identifying states of metabolism exchange will be helpful for an in depth understanding of the macroalgal microbiome.

Metaproteomics is the study of all proteins directly recovered from complex microbial communities. This analysis provides information to gain insights into the functioning of microbial components in the host, beyond the limitation of nucleic acidbased methods (Wilmes and Bond, 2006; Maron et al., 2007). DNA sequence data comprises of many genes with unknown functions and involves a high abundance of unknown functional systems (Tringe et al., 2005). Hence, metaproteomics might prove invaluable for their identification and defining proper functions (Wilmes and Bond, 2006). Complete scanning and characterization of the metaproteome of associated microbiomes is expected to provide data linking the genetic and functional diversity in connection with the specific host (Maron et al., 2007). Additionally, it provides direct evidence for the expressed and functional genes during host-microbial interaction. For example the study by Verberkmoes et al. (2009) employed a shotgun mass spectrometry-based metaproteomics approach and found that more proteins of microbial communities related to 
translation, energy production, and carbohydrate metabolism were observed than those predicted from the metagenomics approaches. Metaproteogenomics of microbial communities of the rice plant revealed that the functional potential of microbial communities depends on their localization, i.e., phyllosphere versus rhizosphere (Knief et al., 2012). The physiological traits of transport processes and stress responses were more prominent in phyllospheric samples whereas dinitrogenase reductase was solely identified in the rhizospheric microbiome, despite the presence of nifH genes in diverse phyllospheric bacterial communities. The functional interaction of the macroalgal microbiome is very poorly understood in view of metaproteomics and metaproteogenomics, despite its complex dynamic functional connection. Particularly, this analysis will help to identify the proteins of associated microbial communities that are involved in morphogenesis and growth of the host macroalga as well as the proteins that are important for development of the microbiome on the host surface. It will also provide an insight into the pathogenicity (possibly via protease and polysaccharide-degrading enzymes) of bacterial pathogens of the macroalga since true pathogens are already known (Vairappan et al., 2001; Zozaya-Valdes et al., 2015).

The metabolome refers to the complete set of smallmolecules produced by an organism and are a representation of the metabolic pathways and networks of the genome. Microbial metabolites can be determined using a number of different technologies including nuclear magnetic resonance spectroscopy and diverse mass spectrometry (Lee et al., 2012a,b). Metabolomics is the study of the metabolome that can potentially provide a perfect portrait of the definite physiological state of a specific microbiome because the intermediates of various biochemical reactions play a vital role in connecting different pathways that operate in active microbial communities (Tyson et al., 2004; Garcia et al., 2008; Nicholson and Lindon, 2008; Tang, 2011; Lu et al., 2014). Thus, microbial metabolomics is an important component of systems biology that facilitates the understanding of integrated microbial functions. Additionally, they are easy to manipulate through pre- and probiotics and have crucial functions in health and growth of different eukaryotic organisms including humans and macroalgae. For example, there are approximately $10^{14}$ bacterial cells present in the human gut belonging to about 1,000 bacterial species that are known to have a direct bearing on individual health (Nicholson et al., 2005; Gill et al., 2006; Kassinen et al., 2007; Atarashi et al., 2011). These microorganisms produce several metabolites (such as butyrate) that are involved in defense against pathogens, maintaining homeostasis, inducing cellular differentiation in the immune system $\left(\mathrm{CD} 4^{+} \mathrm{Foxp}^{+}\right.$regulatory $\mathrm{T}$ cells), secretion of essential anti-inflammatory molecules (interleukin-10 and inducible T-cell co-stimulator), and renewal of gut epithelial cells (Turnbaugh et al., 2007; Atarashi et al., 2011, 2013). The dynamic metabolic flux of plant rhizosphere and bacterial communities is extensively studied in the context of rhizobial interaction with their hosts (Venturi and Fuqua, 2013). Inter-kingdom signaling through AHLs and plant roots has been significantly demonstrated in recent times wherein AHLs produced by bacterial communities were found to assist in plant growth, development, and performance (Hartmann et al., 2014). Similarly, dynamic interactions of controlled metabolism exist between the macroalgal microbiome and co-metabolism, that are contributed by both bacterial communities and the host (Dittami et al., 2014). Notably, few chemical compounds have been identified from associated bacterial communities that determine growth and morphology of Ulva (Wichard et al., 2015). However, several unknown bacterial compounds have been observed to induce morphogenesis in macroalgal hosts (Marshall et al., 2006; Singh et al., 2011). Therefore, microbial metabolomics should be included in macroalgal research for studying the spatiotemporal dynamics of metabolite production in bacterial communities and for identifying potential compounds.

Several bioinformatics softwares and statistical tools are being used to analyze a large amount of raw data obtained from NGS experiments. The information of these tools with brief descriptions is available at http:// bioinformaticssoftwareandtools.co.in/ngs.php. The data generated from these meta-omics technologies will undoubtedly revolutionize our understanding of the macroalgal microbiome under given conditions, particularly in identifying several unknown proteins and active metabolic compounds and the defining regulatory processes of this association. The integrated information of these techniques will allow construction of detailed, high-resolution regulatory maps of biological function for macroalgal-bacterial interaction (Figure 1). The information obtained from these meta-omics technologies will be underpinned to exploit them in the future with respect to development of potential macroalgal probiotics as mentioned below.

\section{MODULATING MACROALGAL MICROBIOME FOR HOST HEALTH AND PERFORMANCE}

The development of NGS was a revolutionary step in microbial ecology that has provided newer insights in understanding the complex host-microbe interactions, especially in the context of non-cultivable microorganisms and finding beneficial microbial species of the host. An artificial consortium of bacterial species representing the beneficial gut microbiome of a healthy person when transferred into the gut of infected mice results in reestablishment of normal microflora and leads to mitigation of the gastro-intestinal diseased condition (Petrof et al., 2013; Narushima et al., 2014). In agriculture, successful plant disease management has been achieved through transferring active beneficial microbiomes by mixing disease suppressive soils with disease conducive soils (Mendes et al., 2011). In another study, shifting of the soil microbiome was achieved through soil solutions in which the modulated microbiome alleviated drought stress in Arabidopsis thaliana (Zolla et al., 2013). These findings suggest that beneficial microbial species would been favored during early development of the host by certain selective pressures, probably on the basis of prevailing environmental conditions and then participated in further development of the host microbiome. 
Successful modulation of beneficial microbial/bacterial species of the human gut and plants has provided new avenues to study the macroalgal microbiome from the context of their interactions and functional relationship with hosts. Implementation of a variety of meta-omics technologies on microbial communities of macroalgae will identify a specific functionally active bacterial species (FABS) and establish their functional relationship with the hosts. Such FABS will serve for improving health of the host by suppressing growth of pathogen(s) and enhance performance by assisting the host physiology. Thus, in the future, macroalgal functional microbiomes will have a greater importance for macroalgal cultivation to continuously supply raw materials for diverse industries and to fulfill human demand. For example, FABS can be identified from healthy individual(s) and be applied to diseased plantlets in order to suppress the growth of pathogen(s) or in case of commercial cultivation, germling fronds may first be treated with the FABS identified in the laboratory and then

\section{REFERENCES}

Adesemoye, A. O., Torbert, H. A., and Kloepper, J. W. (2009). Plant GrowthPromoting rhizobacteria allow reduced application rates of chemical fertilizers. Microb. Ecol. 58, 921-929. doi: 10.1007/s00248-009-9531-y

Andrews, J. H. (1992). Biological control in the phyllosphere. Annu. Rev. Phytopathol. 30, 603-635. doi: 10.1146/annurev.py.30.090192.003131

Atarashi, K., Tanoue, T., Oshima, K., Suda, W., Nagano, Y., Nishikawa, H., et al. (2013). Treg induction by a rationally selected mixture of Clostridia strains from the human microbiota. Nature 500, 232-236. doi: 10.1038/nature12331

Atarashi, K., Tanoue, T., Shima, T., Imaoka, A., Kuwahara, T., Momose, Y., et al. (2011). Induction of colonic regulatory $\mathrm{T}$ cells by indigenous Clostridium species. Science 331, 337-341. doi: 10.1126/science.1198469

Baghel, R. S., Trivedi, N., Gupta, V., Neori, A., Reddy, C. R. K., Lali, A., et al. (2015). Biorefining of marine macroalgal biomass for production of biofuel and commodity chemicals. Green Chem. 17, 2436-2443. doi: 10.1039/c4gc02532f

Bakker, M. G., Manter, D. K., Sheflin, A. M., Weir, T. L., and Vivanco, J. M. (2012). Harnessing the rhizosphere microbiome through plant breeding and agricultural management. Plant Soil 360, 1-13. doi: 10.1007/s11104-012-1361-x

Bengtsson, M. M., Sjotun, K., Lanzen, A., and Ovreas, L. (2012). Bacterial diversity in relation to secondary production and succession on surfaces of the kelp Laminaria hyperborea. ISME J. 6, 2188-2198. doi: 10.1038/ismej.2012.67

Berg, G., and Smalla, K. (2009). Plant species and soil type cooperatively shape the structure and function of microbial communities in the rhizosphere. Fems Microbiol. Ecol. 68, 1-13. doi: 10.1111/j.1574-6941.2009.00654.x

Bikel, S., Valdez-Lara, A., Cornejo-Granados, F., Rico, K., Canizales-Quinteros, S., Soberon, X., et al. (2015). Combining metagenomics, metatranscriptomics and viromics to explore novel microbial interactions: towards a systemslevel understanding of human microbiome. Comput. Struct. Biotechnol. J. 13, 390-401. doi: 10.1016/j.csbj.2015.06.001

Bloemberg, G. V., and Lugtenberg, B. J. (2001). Molecular basis of plant growth promotion and biocontrol by rhizobacteria. Curr. Opin. Plant Biol. 4, 343-350. doi: 10.1016/S1369-5266(00)00183-7

Bondoso, J., Balague, V., Gasol, J. M., and Lage, O. M. (2014). Community composition of the Planctomycetes associated with different macroalgae. Fems Microbiol. Ecol. 88, 445-456. doi: 10.1111/1574-6941.12258

Bulgarelli, D., Schlaeppi, K., Spaepen, S., Ver Loren Van Themaat, E., and SchulzeLefert, P. (2013). Structure and functions of the bacterial microbiota of plants. Annu. Rev. Plant Biol. 64, 807-838. doi: 10.1146/annurev-arplant-050312120106

Burke, C., Steinberg, P., Rusch, D., Kjelleberg, S., and Thomas, T. (2011a). Bacterial community assembly based on functional genes rather than species. Proc. Natl. Acad. Sci. U.S.A. 108, 14288-14293. doi: 10.1073/pnas.1101591108 transferred either into controlled farms or in open seas for improving growth performance.

\section{AUTHOR CONTRIBUTIONS}

RS and CR had designed the outlines of the work. Then, RS has drafted the initial version of the work and CR has substantially improved the quality of the work as well as approved the final version to be published.

\section{ACKNOWLEDGMENTS}

RS gratefully acknowledges the Japan Society for the Promotion of Science (JSPS) for providing Post-doctoral Fellowship. CSIRCSMCRI are also thanked for facilities and encouragement provided while preparing this manuscript.

Burke, C., Thomas, T., Lewis, M., Steinberg, P., and Kjelleberg, S. (2011b). Composition, uniqueness and variability of the epiphytic bacterial community of the green alga Ulva australis. ISME J. 5, 590-600. doi: 10.1038/ismej.2010.164 Caporaso, J. G., Lauber, C. L., Walters, W. A., Berg-Lyons, D., Huntley, J., Fierer, N., et al. (2012). Ultra-high-throughput microbial community analysis on the Illumina HiSeq and MiSeq platforms. ISME J. 6, 1621-1624. doi: 10.1038/ismej.2012.8

Chisholm, J. R. M., Dauga, C., Ageron, E., Grimont, P. A. D., and Jaubert, J. M. (1996). Roots in mixotrophic algae. Nature 381, 565-565. doi: $10.1038 / 381565 \mathrm{~b} 0$

de Oliveira, L. S., Gregoracci, G. B., Silva, G. G., Salgado, L. T., Filho, G. A., Alves-Ferreira, M., et al. (2012). Transcriptomic analysis of the red seaweed Laurencia dendroidea (Florideophyceae, Rhodophyta) and its microbiome. BMC Genomics 13:487. doi: 10.1186/1471-2164-13-487

Dittami, S. M., Eveillard, D., and Tonon, T. (2014). A metabolic approach to study algal-bacterial interactions in changing environments. Mol. Ecol. 23, 1656-1660. doi: $10.1111 / \mathrm{mec} .12670$

FAO (2014). The State of World Fisheries and Aquaculture: Opportunities and Challenges, Rome, 243.

Fuqua, W. C., Winans, S. C., and Greenberg, E. P. (1994). Quorum Sensing in Bacteria - the LuxR-LuxI Family of Cell Density-Responsive Transcriptional Regulators. J. Bacteriol. 176, 269-275.

Garcia, D. E., Baidoo, E. E., Benke, P. I., Pingitore, F., Tang, Y. J., Villa, S., et al. (2008). Separation and mass spectrometry in microbial metabolomics. Curr. Opin. Microbiol. 11, 233-239. doi: 10.1016/j.mib.2008.04.002

Gill, S. R., Pop, M., Deboy, R. T., Eckburg, P. B., Turnbaugh, P. J., Samuel, B. S., et al. (2006). Metagenomic analysis of the human distal gut microbiome. Science 312, 1355-1359. doi: 10.1126/science. 1124234

Grice, E. A., Kong, H. H., Conlan, S., Deming, C. B., Davis, J., Young, A. C., et al. (2009). Topographical and temporal diversity of the human skin microbiome. Science 324, 1190-1192. doi: 10.1126/science.1171700

Hahn-Hägerdal, B., Galbe, M., Gorwa-Grauslund, M. F., Lidén, G., and Zacchi, G. (2006). Bio-ethanol-the fuel of tomorrow from the residues of today. Trends Biotechnol. 24, 549-556. doi: 10.1016/j.tibtech.2006.10.004

Hartmann, A., Rothballer, M., Hense, B. A., and Schroder, P. (2014). Bacterial quorum sensing compounds are important modulators of microbe-plant interactions. Front. Plant Sci. 5:131. doi: 10.3389/fpls.2014.00131

Hollants, J., Decleyre, H., Leliaert, F., De Clerck, O., and Willems, A. (2011). Life without a cell membrane: challenging the specificity of bacterial endophytes within Bryopsis (Bryopsidales, Chlorophyta). BMC Microbiol. 11:255. doi: 10.1186/1471-2180-11-255

Hollants, J., Leliaert, F., Verbruggen, H., Willems, A., and De Clerck, O. (2013). Permanent residents or temporary lodgers: characterizing intracellular bacterial 
communities in the siphonous green alga Bryopsis. Proc. Biol. Sci. 280:20122659. doi: $10.1098 / \mathrm{rspb} .2012 .2659$

Joint, I., Tait, K., Callow, M. E., Callow, J. A., Milton, D., Williams, P., et al. (2002). Cell-to-cell communication across the prokaryote-eukaryote boundary. Science 298, 1207-1207. doi: 10.1126/science. 1077075

Kan, J., Hanson, T. E., Ginter, J. M., Wang, K., and Chen, F. (2005). Metaproteomic analysis of Chesapeake Bay microbial communities. Saline Syst. 1:7. doi: 10.1186/1746-1448-1-7

Kassinen, A., Krogius-Kurikka, L., Makivuokko, H., Rinttila, T., Paulin, L., Corander, J., et al. (2007). The fecal microbiota of irritable bowel syndrome patients differs significantly from that of healthy subjects. Gastroenterology 133, 24-33. doi: 10.1053/j.gastro.2007.04.005

Kim, M., Lee, K. H., Yoon, S. W., Kim, B. S., Chun, J., and Yi, H. (2013). Analytical tools and databases for metagenomics in the next-generation sequencing era. Genomics Inform. 11, 102-113. doi: 10.5808/GI.2013.11.3.102

Knief, C., Delmotte, N., Chaffron, S., Stark, M., Innerebner, G., Wassmann, R., et al. (2012). Metaproteogenomic analysis of microbial communities in the phyllosphere and rhizosphere of rice. Isme J. 6, 1378-1390. doi: 10.1038/ismej.2011.192

Kolmeder, C. A., and de Vos, W. M. (2014). Metaproteomics of our microbiome - developing insight in function and activity in man and model systems. J. Proteom. 97, 3-16. doi: 10.1016/j.jprot.2013.05.018

Komatsu, T., Fukuda, M., Mikami, A., Mizuno, S., Kantachumpoo, A., Tanoue, H., et al. (2014). Possible change in distribution of seaweed, Sargassum horneri, in northeast Asia under A2 scenario of global warming and consequent effect on some fish. Mar. Pollut. Bull. 85, 317-324. doi: 10.1016/j.marpolbul.2014.04.032

Kostic, A. D., Gevers, D., Pedamallu, C. S., Michaud, M., Duke, F., Earl, A. M., et al. (2012). Genomic analysis identifies association of Fusobacterium with colorectal carcinoma. Genome Res. 22, 292-298. doi: 10.1101/gr.126573.111

Kumari, P., Kumar, M., Gupta, V., Reddy, C. R. K., and Jha, B. (2010). Tropical marine macroalgae as potential sources of nutritionally important PUFAs. Food Chem. 120, 749-757. doi: 10.1016/j.foodchem.2009.11.006

Lachnit, T., Meske, D., Wahl, M., Harder, T., and Schmitz, R. (2011). Epibacterial community patterns on marine macroalgae are host-specific but temporally variable. Environ. Microbiol. 13, 655-665. doi: 10.1111/j.14622920.2010.02371.x

Lebeis, S. L., Rott, M., Dangl, J. L., and Schulze-Lefert, P. (2012). Culturing a plant microbiome community at the cross-Rhodes. New Phytol. 196, 341-344. doi: 10.1111/j.1469-8137.2012.04336.x

Lee, H. J., Jung, J. Y., Oh, Y. K., Lee, S. S., Madsen, E. L., and Jeon, C. O. (2012a). Comparative survey of rumen microbial communities and metabolites across one caprine and three bovine groups, using bar-coded pyrosequencing and ${ }^{1} \mathrm{H}$ nuclear magnetic resonance spectroscopy. Appl. Environ. Microbiol. 78, 5983-5993. doi: 10.1128/AEM.00104-112

Lee, S. Y., Kim, H. Y., Lee, S., Lee, J. M., Muthaiya, M. J., Kim, B. S., et al. (2012b). Mass spectrometry-based metabolite profiling and bacterial diversity characterization of Korean traditional meju during fermentation. J. Microbiol. Biotechnol. 22, 1523-1531. doi: 10.4014/jmb.1207.07003

Liu, L., Li, Y., Li, S., Hu, N., He, Y., Pong, R., et al. (2012). Comparison of next-generation sequencing systems. J. Biomed. Biotechnol. 2012:251364. doi: $10.1155 / 2012 / 251364$

Loureiro, R., Gachon, C. M., and Rebours, C. (2015). Seaweed cultivation: potential and challenges of crop domestication at an unprecedented pace. New Phytol. 206, 489-492. doi: 10.1111/nph.13278

Lu, L., Huggins, T., Jin, S., Zuo, Y., and Ren, Z. J. (2014). Microbial metabolism and community structure in response to bioelectrochemically enhanced remediation of petroleum hydrocarbon-contaminated soil. Environ. Sci. Technol. 48, 4021-4029. doi: 10.1021/es4057906

Mardis, E. R. (2008). Next-generation DNA sequencing methods. Annu. Rev. Genomics Hum. Genet. 9, 387-402. doi: 10.1146/annurev.genom.9.081 307.164359

Maron, P. A., Ranjard, L., Mougel, C., and Lemanceau, P. (2007). Metaproteomics: a new approach for studying functional microbial ecology. Microb. Ecol. 53, 486-493. doi: 10.1007/s00248-006-9196-9198

Marshall, K., Joint, I., Callow, M. E., and Callow, J. A. (2006). Effect of marine bacterial isolates on the growth and morphology of axenic plantlets of the green alga Ulva linza. Microb. Ecol. 52, 302-310. doi: 10.1007/s00248-006-9060-x
Matsuo, Y., Imagawa, H., Nishizawa, M., and Shizuri, Y. (2005). Isolation of an algal morphogenesis inducer from a marine bacterium. Science 307:1598. doi: 10.1126/science. 1105486

Mendes, R., Kruijt, M., De Bruijn, I., Dekkers, E., Van Der Voort, M., Schneider, J. H., et al. (2011). Deciphering the rhizosphere microbiome for diseasesuppressive bacteria. Science 332, 1097-1100. doi: 10.1126/science.1203980

Metzker, M. L. (2010). Sequencing technologies - the next generation. Nat. Rev. Genet. 11, 31-46. doi: 10.1038/nrg2626

Narushima, S., Sugiura, Y., Oshima, K., Atarashi, K., Hattori, M., Suematsu, M., et al. (2014). Characterization of the 17 strains of regulatory T cell-inducing human-derived Clostridia. Gut Microbes 5, 333-339. doi: 10.4161/gmic.28572

Nicholson, J. K., Holmes, E., and Wilson, I. D. (2005). Gut microorganisms, mammalian metabolism and personalized health care. Nat. Rev. Microbiol. 3, 431-438. doi: 10.1038/nrmicro1152

Nicholson, J. K., and Lindon, J. C. (2008). Systems biology: metabonomics. Nature 455, 1054-1056. doi: 10.1038/4551054a

Petrof, E. O., Gloor, G. B., Vanner, S. J., Weese, S. J., Carter, D., Daigneault, M. C., et al. (2013). Stool substitute transplant therapy for the eradication of Clostridium difficile infection: 'RePOOPulating' the gut. Microbiome 1:3. doi: 10.1186/2049-2618-1-3

Provasoli, L. (1958). Effect of plant hormones on ulva. Biol. Bull. 114, 375-384. doi: $10.2307 / 1538992$

Provasoli, L., and Pintner, I. J. (1953). Ecological implications of in vitro nutritional requirements of algal flagellates. Ann. N. Y. Acad. Sci. 56, 839-851. doi: 10.1111/j.1749-6632.1953.tb30262.x

Provasoli, L., and Pintner, I. J. (1980). Bacteria induced polymorphysm in an axenic laboratory strain of Ulva lactuca (Chlorophyceae). J. Phycol. 32, 479-482.

Qin, J., Li, R., Raes, J., Arumugam, M., Burgdorf, K. S., Manichanh, C., et al. (2010). A human gut microbial gene catalogue established by metagenomic sequencing. Nature 464, 59-65. doi: 10.1038/nature08821

Rutherford, S. T., and Bassler, B. L. (2012). Bacterial quorum sensing: its role in virulence and possibilities for its control. Cold Spring Harb. Perspect. Med. 2:a012427. doi: 10.1101/cshperspect.a012427

Schadt, E. E., Turner, S., and Kasarskis, A. (2011). A window into third generation sequencing (vol 19, pg R227, 2010). Hum. Mol. Genet. 20, 853-853. doi: $10.1093 / \mathrm{Hmg} / \mathrm{Ddq} 481$

Siboni, N., Ben-Dov, E., Sivan, A., and Kushmaro, A. (2008). Global distribution and diversity of coral-associated Archaea and their possible role in the coral holobiont nitrogen cycle. Environ. Microbiol. 10, 2979-2990. doi: 10.1111/j.1462-2920.2008.01718.x

Singh, B. K., Bardgett, R. D., Smith, P., and Reay, D. S. (2010). Microorganisms and climate change: terrestrial feedbacks and mitigation options. Nat. Rev. Microbiol. 8, 779-790. doi: 10.1038/Nrmicro2439

Singh, R. P., Baghel, R. S., Reddy, C. R. K., and Jha, B. (2015). Effect of quorum sensing signals produced by seaweed-associated bacteria on carpospore liberation from Gracilaria dura. Front. Plant Sci. 6:117. doi: 10.3389/Fpls.2015.00117

Singh, R. P., Mantri, V. A., Reddy, C. R. K., and Jha, B. (2011). Isolation of seaweed-associated bacteria and their morphogenesis-inducing capability in axenic cultures of the green alga Ulva fasciata. Aquatic Biol. 12, 13-21. doi: 10.3354/Ab00312

Singh, R. P., and Reddy, C. R. K. (2014). Seaweed-microbial interactions: key functions of seaweed-associated bacteria. Fems Microbiol. Ecol. 88, 213-230. doi: 10.1111/1574-6941.12297

Spoerner, M., Wichard, T., Bachhuber, T., Stratmann, J., and Oertel, W. (2012). Growth and thallus morphogenesis of Ulva mutabilis (Chlorophyta) depends on a combination of two bacterial species excreting regulatory factors. J. Phycol. 48, 1433-1447. doi: 10.1111/j.1529-8817.2012. 01231.x

Staufenberger, T., Thiel, V., Wiese, J., and Imhoff, J. F. (2008). Phylogenetic analysis of bacteria associated with Laminaria saccharina. FEMS Microbiol. Ecol. 64, 65-77. doi: 10.1111/j.1574-6941.2008.00445.x

Tait, L. W., and Schiel, D. R. (2011). Legacy effects of canopy disturbance on ecosystem functioning in macroalgal assemblages. PLOS ONE 6:e26986. doi: 10.1371/journal.pone.0026986

Tana, C., Umesaki, Y., Imaoka, A., Handa, T., Kanazawa, M., and Fukudo, S. (2010). Altered profiles of intestinal microbiota and organic acids may be the origin of 
symptoms in irritable bowel syndrome. Neurogastroenterol. Motil. 22:512. doi: $10.1111 / \mathrm{j} .1365-2982.2009 .01427 . x$

Tang, J. (2011). Microbial metabolomics. Curr. Genomics 12, 391-403. doi: $10.2174 / 138920211797248619$

Tatewaki, M., Provasoli, L., and Pintner, I. J. (1983). Morphogenesis of Monostroma oxyspermum (Kutz) Doty (Chlorophyceae) in axenic culture, especially in bialgal culture. J. Phycol. 19, 409-416. doi: 10.1111/j.0022-3646.1983.00409.x

Tringe, S. G., Von Mering, C., Kobayashi, A., Salamov, A. A., Chen, K., Chang, H. W., et al. (2005). Comparative metagenomics of microbial communities. Science 308, 554-557. doi: 10.1126/science.1107851

Tujula, N. A., Crocetti, G. R., Burke, C., Thomas, T., Holmstrom, C., and Kjelleberg, S. (2010). Variability and abundance of the epiphytic bacterial community associated with a green marine Ulvacean alga. Isme J. 4, 301-311. doi: 10.1038/ismej.2009.107

Turnbaugh, P. J., Ley, R. E., Hamady, M., Fraser-Liggett, C. M., Knight, R., and Gordon, J. I. (2007). The human microbiome project. Nature 449, 804-810. doi: 10.1038 /nature 06244

Turnbaugh, P. J., Ley, R. E., Mahowald, M. A., Magrini, V., Mardis, E. R., and Gordon, J. I. (2006). An obesity-associated gut microbiome with increased capacity for energy harvest. Nature 444, 1027-1031. doi: 10.1038/Nature05414

Turner, T. R., James, E. K., and Poole, P. S. (2013). The plant microbiome. Genome Biol. 14:209. doi: 10.1186/gb-2013-14-6-209

Tyson, G. W., Chapman, J., Hugenholtz, P., Allen, E. E., Ram, R. J., Richardson, P. M., et al. (2004). Community structure and metabolism through reconstruction of microbial genomes from the environment. Nature 428, 37-43. doi: $10.1038 /$ nature 02340

Ursell, L. K., and Knight, R. (2013). Xenobiotics and the human gut microbiome: metatranscriptomics reveal the active players. Cell Metab 17, 317-318. doi: 10.1016/j.cmet.2013.02.013

Vairappan, C. S., Suzuki, M., Motomura, T., and Ichimura, T. (2001). Pathogenic bacteria associated with lesions and thallus bleaching symptoms in the Japanese kelp Laminaria religiosa Miyabe (Laminariales, Phaeophyceae). Hydrobiologia 445, 183-191. doi: 10.1023/A:1017517832302

Venturi, V., and Fuqua, C. (2013). Chemical signaling between plants and plantpathogenic bacteria. Annu. Rev. Phytopathol. 51, 17-37. doi: 10.1146/annurevphyto-082712-102239

Verberkmoes, N. C., Russell, A. L., Shah, M., Godzik, A., Rosenquist, M., Halfvarson, J., et al. (2009). Shotgun metaproteomics of the human distal gut microbiota. ISME J. 3, 179-189. doi: 10.1038/ismej.2008.108

Wahl, M., Goecke, F., Labes, A., Dobretsov, S., and Weinberger, F. (2012). The second skin: ecological role of epibiotic biofilms on marine organisms. Front Microbiol. 3:292. doi: 10.3389/Fmicb.2012.00292

Wang, Z., Gerstein, M., and Snyder, M. (2009). RNA-Seq: a revolutionary tool for transcriptomics. Nat. Rev. Genet. 10, 57-63. doi: 10.1038/Nrg2484
Wang, Z. N., Klipfell, E., Bennett, B. J., Koeth, R., Levison, B. S., Dugar, B., et al. (2011). Gut flora metabolism of phosphatidylcholine promotes cardiovascular disease. Nature 472, 57-82. doi: 10.1038/Nature09922

Weinberger, F. (2007). Pathogen-induced defense and innate immunity in macroalgae. Biol. Bull. 213, 290-302. doi: 10.2307/250 66646

Weinberger, F., Beltran, J., Correa, J. A., Lion, U., Pohnert, G., Kumar, N., et al. (2007). Spore release in Acrochaetium sp (Rhodophyta) is bacterially controlled. J. Phycol. 43, 235-241. doi: 10.1111/j.1529-8817.2007.00329.x

Weston, L. A., and Mathesius, U. (2013). Flavonoids: their structure, biosynthesis and role in the rhizosphere, including allelopathy. J. Chem. Ecol. 39, 283-297. doi: 10.1007/s10886-013-0248-245

Wichard, T., Charrier, B., Mineur, F., Bothwell, J. H., Clerck, O. D., and Coates, J. C. (2015). The green seaweed Ulva: a model system to study morphogenesis. Front. Plant Sci. 6:72. doi: 10.3389/fpls.2015.00072

Wilmes, P., and Bond, P. L. (2006). Metaproteomics: studying functional gene expression in microbial ecosystems. Trends Microbiol. 14, 92-97. doi: 10.1016/j.tim.2005.12.006

Yang, Z., and Li, Z. (2012). Spatial distribution of prokaryotic symbionts and ammoxidation, denitrifier bacteria in marine sponge Astrosclera willeyana. Sci. Rep. 2:528. doi: 10.1038/srep00528

Zilber-Rosenberg, I., and Rosenberg, E. (2008). Role of microorganisms in the evolution of animals and plants: the hologenome theory of evolution. FEMS Microbiol. Rev. 32, 723-735. doi: 10.1111/j.1574-6976.2008. 00123.x

Zolla, G., Badri, D. V., Bakker, M. G., Manter, D. K., and Viyanco, J. M. (2013). Soil microbiomes vary in their ability to confer drought tolerance to Arabidopsis. Appl. Soil Ecol. 68, 1-9. doi: 10.1016/j.apsoil.2013.03.007

Zozaya-Valdes, E., Egan, S., and Thomas, T. (2015). A comprehensive analysis of the microbial communities of healthy and diseased marine macroalgae and the detection of known and potential bacterial pathogens. Front. Microbiol. 6:146. doi: 10.3389/Fmicb.2015. 00146

Conflict of Interest Statement: The authors declare that the research was conducted in the absence of any commercial or financial relationships that could be construed as a potential conflict of interest.

Copyright (c) 2016 Singh and Reddy. This is an open-access article distributed under the terms of the Creative Commons Attribution License (CC BY). The use, distribution or reproduction in other forums is permitted, provided the original author(s) or licensor are credited and that the original publication in this journal is cited, in accordance with accepted academic practice. No use, distribution or reproduction is permitted which does not comply with these terms. 